\title{
Challenges of democratic inclusion: Investigating the politics of difference
}

\author{
Astrid Mattes ${ }^{1}$, Jeremias Stadlmair ${ }^{1, *}$ \\ 1 Department of Political Science, University of Vienna, Austria \\ * E-Mail: jeremias.stadlmair@univie.ac.at
}

\begin{abstract}
Contemporary European societies are shaped by ongoing disputes about how to draw boundaries of membership and about the proper means of democratic inclusion. Who - which groups and individuals - should have a voice in the political system and access to resources? How can these actors achieve an equal standing in democratic societies? Sieglinde Rosenberger has contributed important points to these questions and continues to do so: With an emphasis on the Austrian political system in the context of European Integration, she combined research on gender, migration, religion and political participation into a common framework of "Politics of Inclusion and Exclusion". On the occasion of her 6oth birthday, this special issue aims to review the Politics of Inclusion and Exclusion, providing both normative and empirical perspectives.
\end{abstract}

\section{Keywords}

Participation; inclusion/exclusion; democratic inclusion; politics of difference; Austrian Politics

\section{Demokratische Inklusion: Herausforderungen einer Politik der Vielfalt}

\section{Zusammenfassung}

Welche Individuen und Gruppen sollen an demokratischen Institutionen und Verfahren teilhaben? Welche Formen von Teilhabe ermöglichen eine adäquate Berücksichtigung divergierender Interessen? Zur wissenschaftlichen Aufarbeitung dieser Fragen politischer Grenzziehungsprozesse trägt Sieglinde Rosenberger maßgeblich bei: Fokussierend auf das politische System Österreichs im Kontext europäischer Integration vereint Sieglinde Rosenberger Forschung zu Gender, Migration, Religion und politischer Partizipation zum konzeptionellen Rahmen der „Politik der Inklusion und Exklusion“. Anlässlich ihres sechzigsten Geburtstags befasst sich dieses Schwerpunktheft mit normativen wie empirischen Fragen politischer Grenzziehung in den Bereichen Migration, Religion, und Geschlecht und bietet damit eine Zusammenschau des Konzepts Inklusion/Exklusion.

\section{Schlüsselwörter}

Partizipation, Politische Teilhabe, Politik der Differenz, Inklusion/Exklusion, Österreich

The authors have declared that no competing interests exist. 


\section{Introduction}

In 1989 Sieglinde Rosenberger wrote:

Differences of life realities, domination and oppression, are based on interests, some aiming to remain the status quo, others pushing for change - this however, from different positions of power. (1989, 343)

These lines from Sieglinde Rosenberger's dissertation thesis on gender politics could not be more topical today. As we write the introduction for this special issue, the European Union and its member states are challenged by turbulent processes: large numbers of persons seek shelter and a prospect for their lives in Europe, triggering both support and backlash in migration-related discourses and policies. Debates about immigration and its imputed consequences assume an unprecedented significance and polarization (Bauman 20I6). In this context, questions of democratic inclusion attract increasing attention: Who - which groups and individuals - should be regarded as legitimate members of the political community and therefore have a voice in the political system? How can these voices receive an equal standing in society?

In contrast to many current sentiments on immigration, democracies normatively ought to be inclusive and accommodate conviviality in difference (Dahl 1989; Young I990). As the reality in which such principles are to be implemented in is complex and diversified, democratic principles are never uncontested and do not follow the simple black and white logic we tend to find in public discourse. Social scientific research, by contrast, aims to understand and process this complexity by investigating such developments both normatively and empirically. Social sciences play a significant role in developing an understanding of processes of inclusion and exclusion by identifying problematic political concepts and policies that lack inclusionary effects, and by outlining possibilities to overcome exclusion qua difference.

\section{An attempt to grasp Sieglinde Rosenberger's academic contribution}

The multiple challenges of democratic inclusion are the connecting elements of Sieglinde Rosenberger's wideranging research activities. Starting from women's inclusion in the labour market in her early career in Innsbruck (I994 with Brigitte Haller and Karin Liebhart), Rosenberger soon connected gender-relations to the general politics of difference in democratic societies (I996). When Rosenberger was appointed to a full professorship at the University of Vienna in 1998, she was not only one of the first female professors of political science in Austria, but also brought new perspectives and issues to Austrian political science, such as the politics of difference covering gender, religion and ethnicity. All the same, she also worked on more 'conventional' political science, dealing with social policy and distributional justice (2003 with Emmerich Talós), voting (2008 with Gilg Seeber), participation (20I4 with Jeremias Stadlmair), representation (20I6 with Iris Stöckl) and political attitudes (20II with Gilg Seeber). She also advanced the discipline in Austria with her textbook on Austrian politics (one of the very few), which she wrote together with Anton Pelinka, published first in 2000.

Although her rich publication record includes several cross-national studies, the Austrian political system is Rosenberger's core empirical subject, which she has academically observed in its development over recent decades. One such development which she investigated are war memorials as an expression of Austria's struggles of coming to terms with its role as an aggressor in the Second World War (I99I with Reinhold Gärtner). This links into her more recent research on nationalism and right-wing parties (2008 with Nora Gresch and Leila Hadj Abdou). Another line of research deals with the changing role of religion and its institutions in Austrian politics (2007; 20I 4 with Astrid Mattes). Always informed by a desire to facilitate democratic inclusion, Sieglinde Rosenberger's research focus increasingly shifted towards migration research (20IO). Here she combined her fields of expertise to address both normative issues, such as collective identity and common values (20I3 with Birgit Sauer), and pragmatic issues of immigrant integration (20I4 with Florian Trauner). Her strong empirical focus made her sensitive to evolving issues and up-to-date research, a strength she always brings to her work with colleagues in the field. The conceptual framework of politics of inclusion and exclusion spans across Rosenberger's theoretical and empirical research (20I3b with Ilker Ataç).

Sieglinde Rosenberger's research did not only evolve in terms of concepts and topics, but also in the way how research is conducted. In the last decade, she has initiated numerous third-party funded research projects (for an overview on recent projects by Sieglinde Rosenberger and her team, see: http://inex. univie.ac.at/research/), enabling many promising students to become professional academics. In this sense, directing research is to her no end in itself but always intended to make a social impact, to address the broader public, to guide younger colleagues or to motivate students (aims that overlap somewhat).

In this spirit of cooperation, she has conducted research on processes of inclusion and exclusion in democratic states, covering all main categories of difference (Young I990; Benhabib I996; Brubaker 20I3): The VEIL project (Values, Equality and Differences 
in Liberal Democracies) focused on issues of gender and religious diversity, GIVING VOICE (Inclusion through Political Parties) investigated political representation along ethnic categories. Projects like LIVING ROOMS (The Art of Mobilizing Belongings) included a class perspective and applied an innovative approach to conviviality in multiethnic and multi-national societies that combined perspectives of social sciences and modern art. Rosenberger's research focuses on discursive, as well as on institutional, civic and legal, mechanisms of inclusion and exclusion. The SOM (Support and Opposition to Migration) project investigated the politicization of migration on a discursive level, while GOVERNING INTEGRATION (A State Secretariat for Integration) monitored the institutionalization of Austrian immigrant integration politics. TAKING SIDES (Protest Against the Deportation of Asylum Seekers) documents protest movements against deportations and INSIDE (Inside the Deportation Gap - Social Membership for Non-Deported Persons) addresses the situation of people without secure legal status. Conducted with the research group 'INEX - politics of inclusion and exclusion', headed by Sieglinde Rosenberger, these and many other projects investigate the manifold challenges of democratic inclusion.

\section{Conceptualizing inclusion, exclusion and democracy}

As Dahl's (1989) principle of inclusion poses a so-called boundary problem to liberal democracies, questions of who is, should, and is not or should not be, a member of a democratic society are highly contentious. In normative terms, concrete operationalizations of inclusion - such as including all affected interests, all subjected to coercion, and all stakeholders - lead to incongruent outcomes and need to be reconciled (Bauböck in this issue). More generally speaking, questions arise as to how nation states are able to maintain agency and legitimacy in times of transnationally mobile goods and persons (Pelinka in this issue).

Looking at membership in democratic societies from a broader perspective than formal citizenship and access to electoral rights, empirical research on the accommodation, participation and representation of diverse social groups and interests shows that boundaries of democratic membership are contested in several dimensions (Anderson/Hughes 20I5; Ataç/Rosenberger 2013b; Rosenberger/Mourão Permoser 2012; YuvalDavis 2006). In this sense, boundaries involve different legal formats, ranging from humanitarian protection to national citizenship. Boundaries, however, also imply practices which cut across legal distinctions, such as political participation beyond voting, in favour of or opposed to marginalized groups. Boundaries are also vis- ible in terms of attitudes and political discourses, which may be very different to legal categories (Rosenberger/ Seeber 20II; Ruedin and Hadj-Abdou in this issue).

An investigation of intersections of different forms of legal, participatory and discursive boundary-drawing requires a common conceptual framework. Originating from research on social inequality and welfare systems, the concept of inclusion/exclusion addresses the simultaneity of inclusion and exclusion in different social sub-systems (Ataç/Rosenberger 2013b; Kronauer 20IO), such as employment, education, welfare systems, etc. In this framework, inclusion and exclusion are argued to be partial, not absolute. In other words, there are not members and non-members in a political system, but there is a sliding scale of inclusion and exclusion as well as partial memberships. This, however, implies that the demos or the boundary problem outlined above is not only about inclusion, but also about equality: While having a voice or no voice in politics could be understood as a binary question, the perspective of inclusion/exclusion is sensitive to inequalities of political voices, where some political actors are more and some less able to make their interests heard (Verba et al. 1995). Accepting a simultaneity of inclusion and exclusion in stratified social systems is a central assumption of the concept of inclusion/exclusion. However, despite this simultaneity, social systems are not considered to be independent from one another. Their intersections are at the core of a research interest using the approach of inclusion/exclusion. Applied to issues of migration and diversity, this concept helps to investigate legal stratifications of access to citizenship, unequal voices in political participation and representation, as well as the study of discursive boundaries.

\section{Four questions of democratic inclusion and exclusion}

This special issue takes Sieglinde Rosenberger's rich work on different forms, categories, levels and mechanisms of inclusion and exclusion as its point of departure. It is an attempt, on the occasion of her $60^{\text {th }}$ birthday, by scholars who worked with her at different stages of her impressive career to pay tribute to her achievements. To this end we follow her example in addressing pressing issues of democratic inclusion by analysing contemporary developments in the politics of difference. Providing both empirical and normative perspectives, the papers in this special issue reassess questions of inclusion and exclusion in the light of new data and recent political developments, but also develop new perspectives on long-standing controversies of democratic inclusion. The collection of articles is guided by four questions: 
1. How is access to social, political and civic rights negotiated in democratic polities?

2. Which legal and discursive categories shape the construction of boundaries in mobile societies?

3. How are different actors involved in the politics of inclusion and exclusion?

4. How do policies regulating difference impact on democratic inclusion?

Below we provide a brief outline of the contributions in this special issue, discussing how they relate to questions of democratic inclusion and how they might complement Sieglinde Rosenberger's academic work.

\section{Article overview}

Dealing with the question of how social and political rights were extended to foreign residents in Austria, Ilker Ataç's paper goes to the very core of Rosenberger's research, following a rights-based approach of inclusion (Ataç/Rosenberger 20I3a; Marshall 1950). This article builds on empirical cases from Austria which demonstrate how rights of third-country nationals to social assistance and electoral rights in works councils were secured through litigation. In a thick case description, Ataç demonstrates the necessity of providing support structures for legal action as well as the reluctance of institutions to implement court decisions. This article thus refers to questions no. I and 3 , centring on the role of different actors in negotiating citizenship rights.

Also looking at actors involved in processes of inclusion and exclusion, Astrid Mattes investigates the role of faith-based organizations in immigrant integration policy. Case studies from Austria, Germany and Switzerland reveal that these groups fulfil multiple roles as civil society actors, as religious representatives or as migrant associations. Differences occur mainly in relation to Muslim associations: While Austria's legally recognized Islamic Religious Community is involved mainly as a religious representative, German Islamic associations fulfil multiple roles, while Swiss Islamic associations are hardly involved at all. To understand these differences, she applies the perspective of governmentality, which allows her to identify trust and suspicion as central discursive techniques of government.

The use of categories in the construction of boundaries in discourses on immigration (question no. 2) is central to the contributions of Leila Hadj-Abdou and Didier Ruedin. In Leila Hadj-Abdou's discussion article on gender debates by nationalist actors, the category 'religion' is frequently utilized. Hadj-Abdou discusses how nationalist narratives draw on gender roles to push notions of self versus the other and sketches the development of this 'gender nationalism'. Hadj-Abdou identifies both new discursive elements and older ones, apparently inherent to nationalist ideologies, and concludes by pointing at the intersectional mechanisms of exclusion at play.

Drawing on the data of the SOM project, Didier Ruedin investigates the salience and framing of different groups of immigrant minorities in the media in seven European countries. He shows that not only the actors in the debate, but also citizenship regimes (Koopmans et al. 2005) shape the way in which immigrant minorities are portrayed in the media, in particular when it comes to vulnerable or voiceless groups. While the mere size of an immigrant group does not correspond to its politicization, it is often the case that voiceless groups are politicized in a particular type of ethnic regime. Ruedin's text points out the relevance of institutional settings, such as citizenship regimes, for the discursive formation of democratic inclusion and exclusion.

Questions of how immigration-related diversity is debated are also addressed in the contribution of Florian Trauner and Jocelyn Turton: They investigate the phenomenon of a 'welcome culture'. Comparing Austria and Germany, two states that were severely affected by recent inflows of refugees, the authors sketch the course of the debates and the change in meaning of that 'welcome culture' over time. The article demonstrates how this debate reflected the struggles of both societies to come to terms with the challenge of refugee reception. Trauner and Turton contribute to a growing literature on the public contestation of asylum seekers as a social group and of asylum as a human right, which is a core theme of Sieglinde Rosenberger's recent research (Rosenberger 20IO; Rosenberger/Trauner 20I4; Rosenberger/Winkler 2014).

In contrast to the discourse- and actor-centred perspectives in this special issue, Jeremias Stadlmair investigates the social impact of policies regulating democratic inclusion (question no. 4). In a comparison of nine European countries over two decades, he shows to which extent citizenship policies can account for differences in citizenship acquisition via naturalisation. While changes in some naturalisation requirements, such as residence requirements, cannot be directly related to changes in naturalisation rates, it is specifically economic resource requirements which constitute a barrier to democratic inclusion. This article again builds on a rights-based understanding of inclusion/exclusion (Ataç/Rosenberger 20I3a).

As normative contributions, the discussion articles by Anton Pelinka and Rainer Bauböck take a broader perspective on challenges of democratic inclusion. Pelinka addresses the normative challenges of democracy in a globalized world. The "collision of two megatrends", as he describes the concurrent phenomena of democratization and globalization, results in a drifting 
apart of ideas and interests and a lack of congruence between those represented and those affected by democratic politics. In drawing two future scenarios - an optimistic and a pessimistic one - the article demonstrates the necessity of structures of global government to prevent violent confrontations and continue the success story of democratic politics.

Similarly, Rainer Bauböck's discussion article is a theoretical contribution to the normative question whose interests should be involved in democratic processes, and how. Bauböck shows that the demos problem of democratic inclusion can be resolved when combining the principles of 'all affected interests', 'all subjected to coercion', and the 'stakeholder principle'. In contrast to common assumptions, which take these approaches as competing principles, Bauböck proposes a multi-level model of democratic inclusion to reconcile them. He argues that one has to draw on the different objectives of these principles to resolve the demos problem.

Taken together, the articles of this special issue cover a broad spectrum of comparative perspectives across European countries and different aspects of the political sphere, enriched by theoretical debates of normative foundations of democratic inclusion. In doing so, we hope to contribute to the social scientific debate on inclusion and exclusion in democratic societies that face multiple challenges, from the micro-level of individual struggles for equal rights to macro-level developments such as globalization.

\section{Literature}

Anderson, Bridget/Vanessa Hughes (eds.) (2015). Citizenship and its Others, London.

Ataç, Ilker/Sieglinde Rosenberger (2OI3a). Inklusion/ Exklusion - ein relationales Konzept der Migrationsforschung, in: Ilker Ataç/Sieglinde Rosenberger (eds.): Politik der Inklusion und Exklusion, Vienna, 35-52.

Ataç, Ilker/Sieglinde Rosenberger (eds.) (2013b). Politik der Inklusion und Exklusion, Vienna.

Bauman, Zygmunt (2016). Die Angst vor den anderen: ein Essay über Migration und Panikmache, Berlin.

Benhabib, Seyla (1996). The Democratic Movement and the Problem of Difference, in: Seyla Benhabib (ed.): Democracy and Difference: Contesting the Boundaries of the Political, Princeton, 3-18.

Brubaker, Rogers (2013). Language, religion and the politics of difference, in: Nations and Nationalism, Vol. I9(I), I-20.

Dahl, Robert (1989). Democracy and Its Critics, New Haven.

Gärtner, Reinhold/Sieglinde Rosenberger (I99I). Kriegerdenkmäler: Vergangenheit in der Gegenwart, Innsbruck.
Gresch, Nora/Leila Hadj-Abdou/Sieglinde Rosenberger/ Birgit Sauer (2008). Tu felix Austria? The Headscarf and the Politics of "Non-issues", in: Social Politics: International Studies in Gender, State \& Society, Vol. I5(4), 4II-432.

Haller, Brigitte/Karin Liebhart/Sieglinde Rosenberger (1994). Feminism and multiculturalism, in: Österreichische Zeitschrift für Politikwissenschaft, Vol. 23(2), 205-2II.

Koopmans, Ruud/Paul Statham/Marco Giugni/Florence Passy (2005). Contested Citizenship: Immigration and Cultural Diversity in Europe, Minneapolis.

Kronauer, Martin (20I0). Exklusion. Die Gefährdung des Sozialen im hoch entwickelten Kapitalismus, Frankfurt am Main/New York.

Marshall, Thomas H. (1950). Citizenship and Social Class: And Other Essays, Cambridge.

Mattes, Astrid/Sieglinde Rosenberger (2015). Islam and Muslims in Austria, in: Ines Michalowski/Marian Burchardt (eds.): After Integration: Islam, Conviviality and Contentious Politics in Europe, Wiesbaden, I29-I52.

Pelinka, Anton/Sieglinde Rosenberger (2000). Österreichische Politik. Grundlagen. Strukturen. Trends, Vienna.

Rosenberger, Sieglinde (1989). Frauenfragen oder Geschlechterfragen. Institutionelle Frauenpolitik in Österreich, Innsbruck.

Rosenberger, Sieglinde (2007). Individuelle Freiheit oder institutionelle Säkularität? Religionen in der liberalen Demokratie, in: Helga Peskoller/Michaela Ralser/Maria Wolf (eds.): Texturen von Freiheit: Beiträge für Bernhard Rathmayr, Innsbruck, I67-I82.

Rosenberger, Sieglinde (ed.) (2010). Asylpolitik in Österreich: Unterbringung im Fokus, Vienna.

Rosenberger, Sieglinde (1996). Geschlechter - Gleichheiten-Differenzen. Eine Denk- und Politikbeziehung, Vienna.

Rosenberger, Sieglinde/Julia Mourão Permoser (2012). Zugehörigkeit mobilisieren, politisieren, de-politisieren. Analysen aus dem Wiener Gemeindebau, in: Florian Bettel/Julia Mourão Permoser/Sieglinde Rosenberger (eds.): living rooms - Politik der Zugehörigkeiten im Wiener Gemeindebau, Vienna/New York, 19-74.

Rosenberger, Sieglinde/Birgit Sauer (2013). Politics, Religion and Gender: Framing and Regulating the Veil, Oxford.

Rosenberger, Sieglinde/Gilg Seeber (2OII). Kritische Einstellungen: BürgerInnen zu Demokratie, Politik, Migration, in: Regina Polak (ed.): Zukunft. Werte. Europa. Die Europäische Wertestudie 1990-20IO: Österreich im Vergleich, Vienna, I65-I89.

Rosenberger, Sieglinde/Gilg Seeber (2008). Wählen, Vienna. Rosenberger, Sieglinde/Jeremias Stadlmair (2014). Partizipation in Österreich, in: Bertelsmann Stiftung, 
Staatsministerium Baden - Wüttemberg (ed.): Partizipation im Wandel - Unsere Demokratie zwischen Wählen, Mitmachen und Entscheiden. Gütersloh, 454-488.

Rosenberger, Sieglinde/Iris Stöckl (2016). The politics of categorization - political representatives with immigrant background between "the other" and "standing for", in: Politics, Groups, and Identities, DOI: IO.IO80/21565503.20I6.II94764, I-20.

Rosenberger, Sieglinde/Emmerich Talos (eds.) (2003). Sozialstaat: Probleme, Herausforderungen, Perspektiven, Vienna.

Rosenberger, Sieglinde/Florian Trauner (eds.) (2014). Themenschwerpunkt Asylpolitik (Special Issue), in: Österreichische Zeitschrift für Politikwissenschaft, Vol. 43(2)

Rosenberger, Sieglinde/Jakob Winkler (20I4). Com/ passionate Protests: Fighting the Deportation of Asylum Seekers, in: Mobilization: An International Quarterly, Vol. I9(2), I65-I84.

Verba, Sidney/Kay L. Schlozman/Henry E. Brady (I995). Voice and Equality: Civic Voluntarism in American Politics, Cambridge.

Young, Iris Marion (I990). Justice and the politics of difference, Princeton.

Yuval-Davis, Nira (2006). Belonging and the politics of belonging, in: Patterns of Prejudice, Vol. 4O(3), I97214 .

\section{Authors}

Astrid Mattes (1988) is $\mathrm{PhD}$ researcher at the Department of Political Science at University of Vienna. She studied Political Science and Comparative Religious Studies in Vienna (Austria) and Limerick (Ireland) and spent research visits at the Universities of Lucerne (Switzerland) and Toronto (Canada). Her research interests include the fields of immigrant integration politics, challenges of pluralism, religious diversity, Islam in Europe and religion-state relations. Latest publication: Special Issue "Institutional Responses to Religious Diversity", Interdisciplinary Journal for Religion and Transformation in Contemporary Society, 2016 (I) (with Kristina Stoeckl and Julia Mourao Permoser).

Jeremias Stadlmair (1987) is a PhD student at the Department of Political Science of the University of Vienna and member of the research group IN:EX Politics of Inclusion and Exclusion. His research interests comprise citizenship and migration policies in Europe, political participation, and direct democracy. Recent publications include: „Die meritokratische Neugestaltung der österreichischen Integrationspolitik zwischen Rhetorik und Policy“, in: Austrian Journal of Political Science (ÖZP),
Vol. 45(I), 20I6, 65-79 (together with Oliver Gruber and Astrid Mattes); „Petitionen und Parlamentarische Bürgerinitiativen: Zivilgesellschaft im Parlament?", in: TransForm - Journal für Zivilgesellschaftliche Innovation, Vol. I, 20I6, 68-IOO (together with Sieglinde Rosenberger). 